\title{
The Influence of Admixtures on the Technological Properties of Fresh Concrete Mixture
}

\author{
Albertas KLOVAS *, Mindaugas DAUKŠYS
}

Department of Civil Engineering Technologies, Kaunas University of Technology, Studentu str. 48, LT-51367 Kaunas, Lithuania

cross $^{\text {ref }}$ http://dx.doi.org/10.5755/j01.ms.21.4.5170

Received 09 September 2014; accepted 13 December 2014

\begin{abstract}
In this research superplasticizing (SP), air voids removing (AVR), viscosity modifying (VM) and air entraining admixtures (AE) were used. The dosage of admixtures was chosen from minimum to maximum values recommended by the manufacturers. To sum up, 7 concrete mixture compositions with SP, 6 with AVR and 6 with VM and the last 6 with $\mathrm{AE}$ admixture were prepared. Water and cement ratio for all the compositions was kept at the same value. According to the results obtained, the usage of SP admixture resulted in significant increase of mixture`s slump and flow however it reduced mixture`s air content and increased its density. Concrete mixture`s properties: slump and flow were almost not affected by the increase of AVR and VM admixtures, however the air content slightly decreased and the density of concrete mixture slightly increased. With the incline of air entraining admixture, mixture`s slump, flow and air content increased, but the density declined. The authors of this study wanted to express the importance of the close link between concrete mixture`s technological and rheological properties. According to the yield stress of concrete mixture it is possible to prognosticate the future problems or various outcomes during or after the concrete mixture's casting process. Keywords: admixtures, slump test, flow table test, air content, superplasticizing, yield stress.
\end{abstract}

\section{INTRODUCTION}

Nowadays high-performance concrete contains not only main constituent materials such as: cement; water; coarse and fine aggregates, but various admixtures as well. Wide variations in terms of workability properties can be caused by different interactions between various mixture`s constituents. Concrete workability is typically evaluated in the field by the results of mixture`s slump and flow table test [1]. The most common reason for poor workability is that the addition of fine particles increases the demand of water due to the increased surface area of the aggregates. However, if there is a scarcity in fine particles, segregation or bleeding can occur. The main reason of using VM admixtures is to reduce segregation or bleeding. [2]. It is widely known that the usage of SP admixture increases mixture`s workability properties [3]. SP content has an effect on the physical, mechanical and structural properties of concrete as well [4]. It is also observed that the workability properties of concrete mixtures can be modified with the addition of mineral additives. The big disadvantage of mineral additives against the chemical admixtures is the reduction in strength when part of the cement is replaced by the mineral additives [5]. Air entrainment is the process where many small air bubbles are incorporated into fresh concrete to become part of the matrix that binds the aggregate together in the hardened concrete. This technique is used for achieving better freeze-thaw resistance and also there is a question about how this admixture affects the quality of concrete surface [6]. However, there are many studies conducted about how AE admixtures help to increase concrete`s durability, but

\footnotetext{
* Corresponding author. Tel.: +370-619-13266; fax.: +370-37-438744

E-mail address: albertas.klovas@ktu.lt (A. Klovas)
}

on the other hand, there is little information how it affects the workability properties of concrete mixture [7-9].

Scientists conducted various tests how mineral and chemical admixtures influence the rheological properties of fresh concrete mixture $[1,2,10,11]$. Yield stress and plastic viscosity are the main rheological properties [12]. It was stated that with the given SP dosage, the rheological properties of concrete mixture reduced with the addition of AE admixture. With the same slump, the air entrained concrete had higher yield stress and lower plastic viscosity. This means that higher shear stress is required to start the flow in the air entrained concrete, but the flow resistance would be lower [10]. Despite that rheological properties of concrete mixture are very informative and give very useful information about the workability of concrete mixtures, but in order to establish these properties it requires special tool rheometer, which is very expensive and it is not designed to be used in situ [12]. Workability of concrete mixture, on the other hand, can be defined by the technological properties, like mixture's slump and flow and these properties can be easily measured at the concrete placing place.

Nowadays, different types of admixtures are used when projecting concrete mixture [13]. The aim of this article was to analyse and establish the complex influence of different use admixtures to the technological properties of concrete mixture.

\section{MATERIALS AND METHODOLOGY}

JSC “Akmenes cementas" (Lithuania) Portland cement CEM II/A-LL 42.5 R was used. Physical and mechanical properties obtained from manufacturer of Portland cement CEM II/A-LL 42.5 $\mathrm{R}$ are given in Table 1. Kvesu quarry washed sand with the fraction of $0 / 4$, bulk density of $1710 \mathrm{~kg} / \mathrm{m}^{3}$ and fineness module of 2.62 was used as fine 
aggregate for concrete mixtures. $0 / 1$ sand fraction $\left(\rho=1520 \mathrm{~kg} / \mathrm{m}^{3}\right.$, fineness module 1.78$)$ was also used as fine aggregate. Gravel with the fraction of $4 / 16$ and bulk density of $1327 \mathrm{~kg} / \mathrm{m}^{3}$ was used as the coarse aggregate. Granulometric composition of aggregates is conducted according to LST EN 12620:2013 and presented in Table 3.

Table 1. Physical and mechanical properties of the Portland cement, CEM II/A-LL 42.5 R

\begin{tabular}{|l|c|}
\hline Specific surface area, $\mathrm{m} 2 / \mathrm{kg}$ & 410 \\
\hline Particle density, $\mathrm{kg} / \mathrm{m} 3$ & 3.05 \\
\hline Normal consistency of cement paste, $\%$ & 26.5 \\
\hline Volume stability, $\mathrm{mm}$ & 0.8 \\
\hline Initial setting time, min. & 195 \\
\hline Compressive strength after 2 days /28 days, $\mathrm{MPa}$ & $27.1 / 54.0$ \\
\hline Loss on ignition, \% & 5.05 \\
\hline Insoluble materials, $\%$ & - \\
\hline $\mathrm{SO}_{3}, \%$ & 2.48 \\
\hline $\mathrm{Cl}^{-}, \%$ & 0.015 \\
\hline $\mathrm{Alkalis}$, calculated by $\mathrm{Na}_{2} \mathrm{O}$ equivalent, $\%$ & $<0.8$ \\
\hline
\end{tabular}

7 concrete mixture compositions with SP (CMsp), 6 with AVR (CMavr) and 6 with VM (CMvm) and the last 6 with AE chemical admixtures (CMae) were prepared. Table 4 shows the concrete mixture compositions with different admixtures used. The amount of each admixture was chosen according to recommendations of the manufacturers. Concrete mixture compositions were constructed according to LST 1974:2012 standard requirements.

Table 2 describes admixtures which were used in this research.

Table 2. Description of admixtures used in the research

\begin{tabular}{|c|c|c|c|c|}
\hline & $\begin{array}{c}\text { Glenium } \\
\text { SKY 628 }\end{array}$ & $\begin{array}{c}\text { Rheomix } \\
880\end{array}$ & $\begin{array}{c}\text { Rheomatrix } \\
100\end{array}$ & $\begin{array}{c}\text { Microair } \\
\text { G (LP) }\end{array}$ \\
\hline Purpose & $\begin{array}{c}\text { Super- } \\
\text { plasticizer } \\
\text { (SP) }\end{array}$ & $\begin{array}{c}\text { Air voids } \\
\text { remover } \\
\text { (AVR) }\end{array}$ & $\begin{array}{c}\text { Viscosity } \\
\text { modifier } \\
\text { (VM) }\end{array}$ & $\begin{array}{c}\text { Air } \\
\text { entertainer } \\
\text { (AE) }\end{array}$ \\
\hline $\begin{array}{c}\text { Compound- } \\
\text { based }\end{array}$ & $\begin{array}{c}\text { Polycar- } \\
\text { boxylate }\end{array}$ & $\begin{array}{c}\text { Propoxylate } \\
\text { - etoxylate }\end{array}$ & $\begin{array}{c}\text { Synthetic- } \\
\text { copolymer }\end{array}$ & $\begin{array}{c}\text { Modified - } \\
\text { resin }\end{array}$ \\
\hline Dosage, \% & $0.6-1.8$ & $0-0.3$ & $0-1.1$ & $0-0.3$ \\
\hline $\begin{array}{c}\text { Density, } \\
\text { g/cm3 }\end{array}$ & $1.06-1.10$ & $0.97-0.02$ & $1.0-1.02$ & $0.98-1.04$ \\
\hline $\begin{array}{c}\text { Viscosity, } \\
\text { mPa.s }\end{array}$ & - & $<600$ & - & - \\
\hline pH & - & - & $6-9$ & $9-11$ \\
\hline $\begin{array}{c}\text { Chloride } \\
\text { quantity, } \\
\%\end{array}$ & $<0.1$ & - & $<0.1$ & $<0.01$ \\
\hline
\end{tabular}

Firstly SP was added to concrete mixture in order to determine the optimal quantity. The optimal quantity was determined according to mixture`s workability. Mixture`s slump and flow was pushed as high as possible avoiding segregation. The same addition principle for other chemical admixtures was used.
During the research, dry aggregates were used for concrete mixtures. Cement and aggregates were dosed by weight while water and chemical admixture were dosed by volume. When preparing the concrete mixture, $90 \%$ of water was instantly poured to the mix. Super-plasticizing admixture was mixed with $10 \%$ of water and poured into the mixer. Remaining admixtures were dozed directly to the mix.

The consistency of fresh concrete mixture was evaluated according to: LST EN 12350-2:2009 and LST EN 12350-5:2009 standards. Density was evaluated according to LST EN 12350-6:2009 standard. Air content was evaluated according to LST EN 12350-7:2009 standard. The results were calculated as the average of two tests conducted.

Table 3. Granulometric composition of the aggregates

\begin{tabular}{|c|c|c|c|}
\hline \multirow{2}{*}{$\begin{array}{c}\text { Radius of the } \\
\text { sieve's mesh, } \\
\text { mm }\end{array}$} & \multicolumn{2}{|c|}{ The amount of poured out material, \% } \\
\cline { 2 - 4 } & $\begin{array}{c}\text { Sand } \\
\text { fraction 0/1 }\end{array}$ & $\begin{array}{c}\text { Sand } \\
\text { fraction 0/4 }\end{array}$ & $\begin{array}{c}\text { Gravel } \\
\text { fraction 4/16 }\end{array}$ \\
\hline 16.0 & 100.00 & 100.00 & 98.80 \\
\hline 8.0 & 100.00 & 100.00 & 42.10 \\
\hline 4.0 & 100.00 & 95.10 & 4.30 \\
\hline 2.0 & 99.80 & 81.80 & 1.00 \\
\hline 1.0 & 99.10 & 54.60 & 0.52 \\
\hline 0.500 & 77.40 & 12.40 & 0.44 \\
\hline 0.250 & 2.20 & 0.70 & 0.36 \\
\hline 0.125 & 0.50 & 0.30 & 0.32 \\
\hline 0.000 & 0.00 & 0.00 & 0.00 \\
\hline
\end{tabular}

Table 4. Concrete mixture compositions

\begin{tabular}{|c|c|c|c|c|c|}
\hline \multirow[t]{2}{*}{ Materials } & \multirow[t]{2}{*}{ Unit } & \multicolumn{4}{|c|}{$\begin{array}{l}\text { Concrete mixture compositions } \\
\text { marking. Amount of materials for } \\
1 \mathrm{~m}^{3} \text { concrete mixture }\end{array}$} \\
\hline & & CMp & CMar & $\mathrm{CMv}$ & CMae \\
\hline Cement & $\mathrm{kg}$ & 380 & 380 & 380 & 380 \\
\hline Water & 1 & 178 & 178 & 178 & 178 \\
\hline $\begin{array}{l}\text { Course aggregate, } \\
\text { gravel }-4 / 16\end{array}$ & $\mathrm{~kg}$ & 986 & 986 & 986 & 986 \\
\hline $\begin{array}{l}\text { Fine aggregate, sand } \\
-0 / 4\end{array}$ & $\mathrm{~kg}$ & 574 & 574 & 574 & 574 \\
\hline $\begin{array}{l}\text { Fine aggregate, sand } \\
-0 / 1\end{array}$ & $\mathrm{~kg}$ & 286 & 286 & 286 & 286 \\
\hline $\begin{array}{l}\text { Superplasticizing } \\
\text { admixture }\end{array}$ & $\%$ & $0.6-1.8$ & 1.4 & 1.4 & 1.4 \\
\hline $\begin{array}{l}\text { Viscosity modifying } \\
\text { admixture }\end{array}$ & $\%$ & - & - & $0.1-1.1$ & - \\
\hline $\begin{array}{l}\text { Air voids removing } \\
\text { admixture }\end{array}$ & $\%$ & - & $0.05-0.3$ & - & - \\
\hline $\begin{array}{l}\text { Air entraining } \\
\text { admixture }\end{array}$ & $\%$ & - & - & - & $0.05-0.3$ \\
\hline $\begin{array}{l}\text { Water and cement } \\
\text { ratio }\end{array}$ & - & 0.47 & 0.47 & 0.47 & 0.47 \\
\hline
\end{tabular}




\section{RESULTS}

3.1. The influence of SP admixture on the technological properties of concrete mixture

Fig. 1 indicates how the technological properties of concrete mixture are influenced by SP admixture. The compositions of concrete mixtures used in this research are presented in Table 4. The amount (percentages) of admixtures were calculated and changed according to the quantity of cement. SP dosage: $0.6 \% ; 0.8 \% ; 1.0 \% ; 1.2 \%$; $1.4 \% ; 1.6 \% ; 1.8 \%$ of cement.

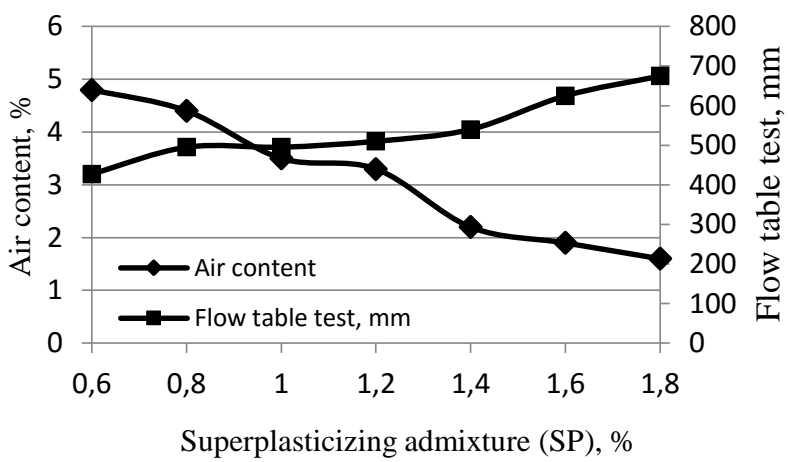

Fig. 1. The influence of SP admixture on the technological properties of CMsp concrete mixture

As can be obtained from Fig. 1 flow table test results indicated the increase from $430 \mathrm{~mm}(0.6 \%$ of $\mathrm{SP})$ to $680 \mathrm{~mm}$ ( $1.8 \%$ of SP). The class of concrete mixture flow according to LST EN 12350-5:2009 standard changed from F3 (420 mm - $480 \mathrm{~mm})$ to F6 (>630 mm).

The air content was constantly reduced when adding SP. With the optimal amount of SP $(1.4 \%)$ the air content was $2.2 \%$. However, the addition more than $1.4 \%$ resulted in mixture's segregation, which is considered the bad factor and further this type of concrete mixture is not investigated.

\subsection{The influence of SP and AVR admixtures on the technological properties of concrete mixture}

Fig. 2 indicates the influence of SP and AVR admixture on the technological properties of concrete mixture. AVR admixture was changed accordingly: $0 \%$; $0.05 \% ; 0.10 \% ; 0.15 \% ; 0.20 \% ; 0.25 \% ; 0.30 \%$ and SP admixture was kept constant at $1.4 \%$ of cement's quantity.

As can be seen from Fig. 2, the addition of SP (constant $1.4 \%$ of cement) and AVR admixture did not result significant changes in mixture`s flow. Mixture`s flow value without AVR admixture was $540 \mathrm{~mm}$. Mixture`s flow with $0.3 \%$ of AVR admixture was $605 \mathrm{~mm}$. Mixture`s flow class increased from F4 $(490 \mathrm{~mm}-550 \mathrm{~mm})$ to F5 (560 mm - $620 \mathrm{~mm})$.

Air content of concrete mixture was reduced from $2.2 \%$ (without admixture) to $1.95 \%(0.3 \%$ of AVR admixture). However, bigger difference between AVR dosage of $0.15 \%$ (air content $2 \%$ ) and dosage of $0.3 \%$ (air content $1.95 \%$ ) was not noticed. To sum up, this kind of admixture is mainly used to reduce the air bubble quantity in the concrete mixture and therefore to obtained better quality of monolithic concrete surfaces. Research revealed that bigger quantity ( $>0.15 \%$ of cement) of this admixture did not influence mixture`s technological properties.

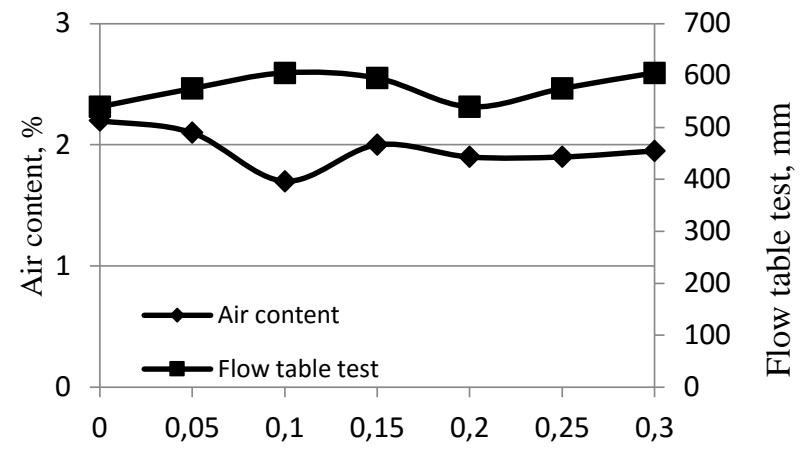

Air voids removing admixture, $\%$

Fig. 2. The influence of AVR admixture on the technological properties of CMavr concrete mixture

\subsection{The influence of SP and VM admixtures on the technological properties of concrete mixture}

Fig. 3 indicates the influence of VM admixture on the technological properties of concrete mixture. VM admixture was dosed accordingly: $0 \% ; 0.1 \%$; $0.3 \%$; $0.5 \% ; 0.7 \% ; 0.9 \% ; 1.1 \%$ and SP admixture was kept constant at $1.4 \%$ of cement's quantity.

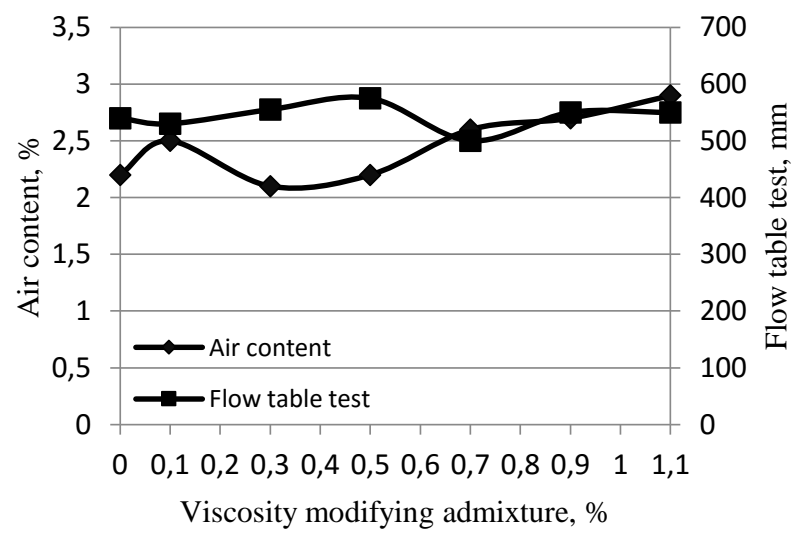

Fig. 3. The influence of VM admixture on the technological properties of CMvm concrete mixture

As can be seen from Fig. 3, the addition of SP (1.4\% of cement's quantity) and VM admixture did not result significant changes in mixture`s flow. Mixture`s flow without the admixture was $540 \mathrm{~mm}$. Mixture`s flow with $1.1 \%$ of VM admixture was $550 \mathrm{~mm}$. Mixture`s flow class remained the same F4 (490 $\mathrm{mm}-550 \mathrm{~mm})$.

The air content of concrete mixture increased with the addition of VM admixture from $2.2 \%$ (without VM) to $2.9 \%(1.1 \%$ of $\mathrm{VM})$.

\subsection{The influence of $S P$ and $A E$ admixtures on the technological properties of concrete mixture}

Fig. 4 indicates the influence of AE admixture on the technological properties of concrete mixture. AE admixture was dosed accordingly: $0 \% ; 0.05 \% ; 0.10 \%$; $0.15 \% ; 0.20 \% ; 0.25 \% ; 0.30 \%$ and SP admixture was kept constant at $1.4 \%$ of cement`s quantity. 


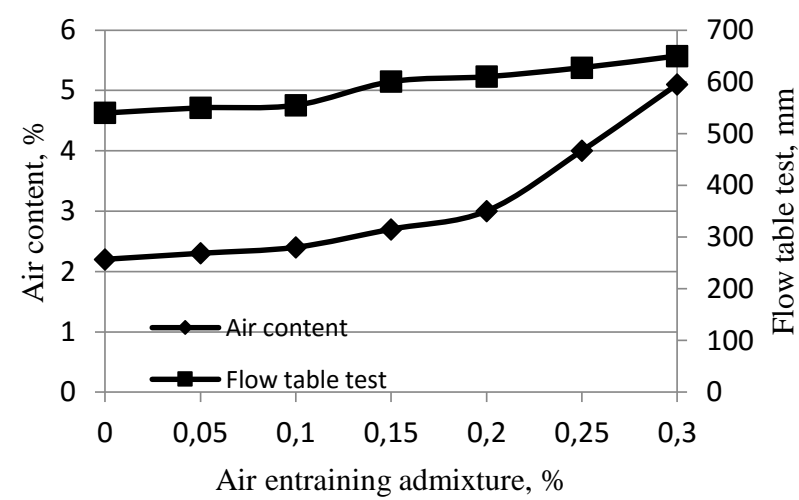

Fig. 4. The influence of $\mathrm{AE}$ admixture on the technological properties of CMae concrete mixture

According to Fig. 4, with the addition of SP (1.4\% of cement`s quantity) and $\mathrm{AE}$ admixture mixture`s flow increased. Mixture`s flow increased from $540 \mathrm{~mm}$ (without admixture) to $650 \mathrm{~mm}$ (0.3\% of $\mathrm{AE}$ admixture). According to LST EN 12350-5:2009 standard, flow`s class changed from F4 (490 mm-550 mm) to F6 (> $630 \mathrm{~mm})$.

It is obvious that air content of concrete mixture increased. This happened because air entraining chemical admixture was used. Air content increased from $2.2 \%$ (without admixture) to $5.1 \%$ ( $0.3 \%$ of admixture).

\section{DISCUSSION}

Tests with the usage of concrete mixture's main chemical admixtures were carried out. These results are very useful for contractors who are working with the production of concrete mixture. It is also valuable for insitu concrete mixture production in low quantities. It combines and explains the findings of the usage of 4 different types of chemical admixtures with the dosages (from minimum to maximum) recommended by the producers.

According to the Eq. 1 [14], concrete mixture`s technological properties are closely connected with mixture`s rheological properties, therefore it is easier to approximately establish concrete mixture`s yield stress just by knowing its slump and density.

$\tau_{0}=\frac{0.00815 \cdot \rho_{m}}{\left(\sqrt{\frac{0.498}{30-S L}-0.001724}-0.024\right)^{2}}$,

where $\tau_{0}$ is the yield stress, $\mathrm{Pa} ; \rho_{m}$ is the concrete mixture`s density, $\mathrm{kg} / \mathrm{m} 3 ; \mathrm{SL}$ is the slump of concrete mixture, $\mathrm{cm}$.

It is said that with the addition of super-plasticizer the yield stress of concrete mixture reduces [10].

Fresh cementitious materials behave as fluids with a yield stress which is the minimum stress for irreversible deformation and flow to occur [15]. Concrete yield stress and viscosity generally increase with the uncompacted void content. Concrete mixture's rheological properties help to obtain the optimization of the product [16].

Concrete can be considered as a two phase material which consists of coarse aggregate (CA) and mortar [17]. Experimental results indicated that higher content of coarse and fine aggregate result in higher concrete rheological parameters (in this case - yield stress). The quality of fresh concrete can be determined by its homogeneity and the ease with which it can be mixed, transported, compacted and finished [18]. According to the previously conducted test results (Figure 9), if concrete mixture becomes stiffer its yield stress increases (plastic viscosity is not affected) and on the other hand, if mixture becomes more viscous, its plastic viscosity increases (yield stress is not affected). Both: plastic viscosity and yield stress are bound to decrease if the mixture becomes wetter [12]. Authors of this study prepared Figure 5, which represents the influence of admixture type and quantity change on the yield stress of concrete mixture. As can be obtained from Figure 5, most of the admixtures had the trend to decline the yield stress. The most significant drop of yield stress indicates the use of SP admixture. The second biggest decline represents the use of $\mathrm{AE}$ admixture and the least decrease is with AVR admixture. On the other hand, the usage of VM admixture had the trend to keep the yield stress of concrete mixture steady.

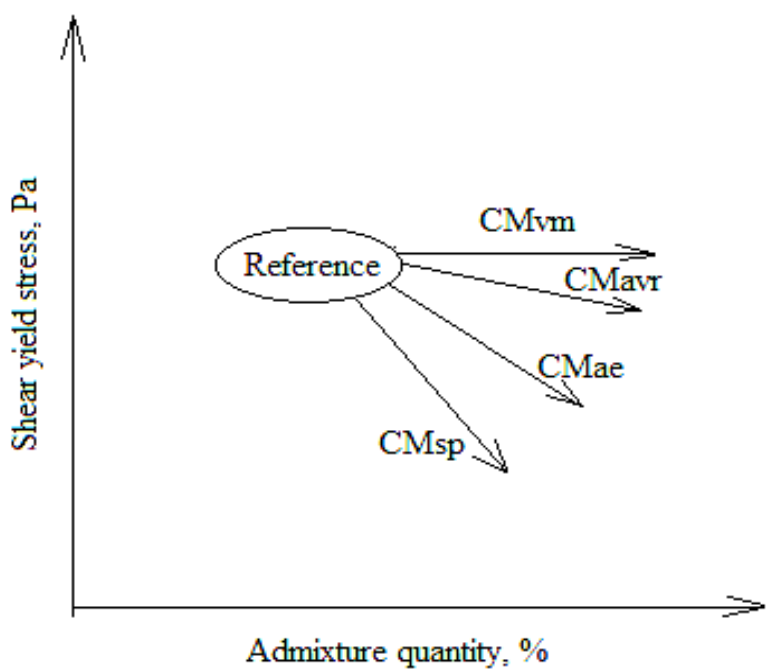

Fig. 5. Principal illustration showing the effect on mixture`s yield stress of adding different admixtures

Table 5 provides data how the yield stress is changed depending on the chemical admixtures which were used in this study. The calculation is conducted according to Eq. 1.

As can be obtained from Table 5, the addition of SP admixture drastically increased mixture`s slump (from S3 to S5 class according to LST EN 206-1:2000) and decreased the yield stress. The density of concrete mixture reached the peak of $2390 \mathrm{~kg} / \mathrm{m} 3$ with $1.4 \%$ of SP. The addition of AVR and AE admixtures slightly changed mixture`s slump and noticeably decreased its yield stress. Mixture`s slump changed within the S5 class limits with the use of AVR and AE admixtures. The bigger influence on mixture`s density was not noticed. The addition of VM admixture almost did not affect nor mixture's slump (changed within S5 class limits) or yield stress, but slightly decreased its density.

Based on rheological studies [19, 20], the yield stress values obtained in this research meet the normal concrete mixture`s yield stress values. 
Table 5. The dependence between mixture`s yield stress, slump and density as well as the admixture used

\begin{tabular}{|c|c|c|c|}
\hline \multicolumn{4}{|c|}{ CMsp mixture } \\
\hline $\begin{array}{c}\text { SP } \\
\text { quantity, \% }\end{array}$ & $\begin{array}{l}\mathrm{SL}, \\
\mathrm{cm}\end{array}$ & $\begin{array}{c}\rho, \\
\mathrm{kg} / \mathrm{m} 3\end{array}$ & $\begin{array}{l}\tau 0 \\
\mathrm{~Pa}\end{array}$ \\
\hline 0.6 & 14 & 2360 & 884.5 \\
\hline 0.8 & 22 & 2370 & 391.9 \\
\hline 1.0 & 22 & 2360 & 390.2 \\
\hline 1.2 & 22 & 2360 & 390.2 \\
\hline 1.4 & 25 & 2390 & 233.5 \\
\hline 1.6 & 26 & 2390 & 182.8 \\
\hline 1.8 & 27 & 2390 & 134.0 \\
\hline \multicolumn{4}{|c|}{ CMavr mixture } \\
\hline $\begin{array}{c}\text { AVR } \\
\text { quantity, } \%\end{array}$ & $\begin{array}{l}\mathrm{SL}, \\
\mathrm{cm}\end{array}$ & $\begin{array}{c}\rho, \\
\mathrm{kg} / \mathrm{m} 3\end{array}$ & $\begin{array}{c}\text { Yield stress, } \\
\mathrm{Pa}\end{array}$ \\
\hline 0.05 & 25 & 2390 & 395.2 \\
\hline 0.10 & 22 & 2390 & 285.7 \\
\hline 0.15 & 25 & 2390 & 233.5 \\
\hline 0.20 & 24 & 2390 & 285.7 \\
\hline 0.25 & 25 & 2390 & 233.5 \\
\hline 0.30 & 25 & 2390 & 233.5 \\
\hline \multicolumn{4}{|c|}{ CMvm mixture } \\
\hline $\begin{array}{c}\text { VM } \\
\text { quantity, \% }\end{array}$ & $\begin{array}{l}\mathrm{SL}, \\
\mathrm{cm}\end{array}$ & $\begin{array}{c}\rho, \\
\mathrm{kg} / \mathrm{m} 3\end{array}$ & $\begin{array}{c}\text { Yield stress, } \\
\mathrm{Pa}\end{array}$ \\
\hline 0.10 & 24 & 2390 & 285.7 \\
\hline 0.30 & 25 & 2390 & 233.5 \\
\hline 0.50 & 24 & 2390 & 285.7 \\
\hline 0.70 & 25 & 2370 & 231.5 \\
\hline 0.90 & 24 & 2370 & 283.4 \\
\hline 1.10 & 24 & 2370 & 283.4 \\
\hline \multicolumn{4}{|c|}{ CMae mixture } \\
\hline $\begin{array}{c}\mathrm{AE} \\
\text { quantity, } \%\end{array}$ & $\begin{array}{l}\mathrm{SL}, \\
\mathrm{cm}\end{array}$ & $\begin{array}{c}\rho, \\
\mathrm{kg} / \mathrm{m} 3\end{array}$ & $\begin{array}{c}\text { Yield stress, } \\
\mathrm{Pa}\end{array}$ \\
\hline 0.05 & 25 & 2370 & 231.5 \\
\hline 0.10 & 25 & 2380 & 232.5 \\
\hline 0.15 & 26 & 2360 & 180.5 \\
\hline 0.20 & 27 & 2370 & 132.8 \\
\hline 0.25 & 27 & 2370 & 132.8 \\
\hline 0.30 & 28 & 2360 & 85.9 \\
\hline
\end{tabular}

The authors of this study wanted to express the importance of the close link between concrete mixture`s technological and rheological properties. According to the yield stress of concrete mixture it is possible to predict the future problems or various outcomes during or after the concrete mixture's casting process. The value of yield stress can express: the possibility to obtain nice concrete surfaces; the ease with which it is possible to work with the concrete mixture in the forms; the possibility of bleeding occurrence; the risk of segregation; the possibility of rough casting joints to occur; the risk of blowholes to appear; the cohesiveness of concrete mixture and others [21].

\section{CONCLUSIONS}

1. The consistency of concrete mixture according to slump increased from S3 to S5 and according to flow increased from F3 to F6 while increasing the amount of superplasticizing polycarboxylate based admixture. With the increase of superplasticizer, the air content decreased and mixture's density increased.

2. In order to change the technological properties of concrete mixture the usage of both superplasticizer and air voids removing admixture is not appropriate, because the significant influence is noticed just by adding superplasticizer alone. The addition of air voids removing admixture did not influence mixture`s consistency.

3. The amount of synthetic - copolymer based viscosity modifying admixture did not influence the consistency of concrete mixture. The slump changed within S5 class limits and flow changed within F4 class limits. Viscosity modifying admixture (with $1.4 \%$ of SP) increased the amount of mixture`s air content by $32 \%$ and decreased its density by $0.8 \%$.

4. Modified-resin based air entraining admixture in conjunction of with $1.4 \%$ of superplasticizer had bigger influence on mixture's flow (increased from F4 to F6) than slump (stayed within S5 class limits). With the increase of air-entraining chemical admixture from $0.05 \%$ to $0.30 \%$, the air content increased about $131 \%$ (from $2.2 \%$ to $5.1 \%$ ) and mixture`s density decreased from $2370 \mathrm{~kg} / \mathrm{m} 3$ to $2360 \mathrm{~kg} / \mathrm{m} 3$.

\section{Acknowledgments}

Albertas Klovas acknowledges support by project "Promotion of Student Scientific Activities" (VP1-3.1ŠMM-01-V-02-003) from the Research Council of Lithuania. This project is funded by the Republic of Lithuania and European Social Fund under the 2007-2013 Human Resources Development Operational Programme's priority 3 .

\section{REFERENCES}

1. Chiara, F. F., Kartthik, H. The Influence of Mineral Admixtures on the Rheology of Cement Paste and Concrete Cement and Concrete Research 31 2001: pp. 245-255.

2. Golaszewski, J. Influence of Viscosity Enhancing Agent on Rheology and Compressive Strength of Superplasticized Mortars Journal of Civil Engineering and Management 15 (2) 2009: pp. $181-188$.

3. Boris, R., Kičaitè, A. The Influence of Plasticizing Admixture on The Rheological Properties of Concrete Mixture 14th conference of Lithuania's young scientists Science-the future of Lithuania 2011: pp. 1-6.

4. Nagrockienė, D., Gailius, A., Skripkiūnas, G., Pundienė, I., Girskas, G., Abasova, A. The Effect of Plasticizing Admixture on the Physical and Mechanical Properties of Concrete with Limestone Cement Materials Science (Medžiagotyra) 19 (3): 2013: pp. 337-342.

5. Şahmaran, M., Christianto, H. A., Yaman, Y. O. The Effect of Chemical Admixtures and Mineral Additives on the Properties of Self-Compacting Mortars Cement and Concrete Composites 28 (5) 2006: pp. 432-440. 
6. Zhang, D. S. Air Entrainment in Fresh Concrete with PFA Cement and Concrete Composites 18 (6) 1996: pp. 409-416. http://dx.doi.org/10.1016/S0958-9465(96)00033-9

7. Laźniewska-Piekarczyk, B. The Type of Air-entraining and Viscosity Modifying Admixtures and Porosity and Frost Durability of High Performance Self-compacting Concrete Construction and Building Materials 40 (1) 2013: pp. 659-671.

8. Chatterji, S. Freezing of Air-entrained Cement-based Materials and Specific Actions of Air-entraining Agents Cement and Concrete Composites 25 (7) 2003: pp. $759-765$.

9. Van den Heede, P., Furniere, J., De Belie, N. Influence of Air Entraining Agents on Deicing Salt Scaling Resistance and Transport Properties of High-volume Fly Ash Concrete Cement and Concrete Composites 37 (1) 2013: pp. $293-303$.

10. Zhang, M. H., Chia, S. Influence of Chemical Admixtures on Workability of Lightweight Aggregate Concrete International Congress on the Chemistry of Cement. CDROM Edition. Chemistry of Cement. International Congress; 12th, Chemistry of Cement 2007: pp. 1-12.

11. Park, C. K., Noh, M. H., Park, T. H. Rheological Properties of Cementitious Materials Containing Mineral Admixtures Cement and Concrete Research 35 (5) 2005: pp. $842-849$.

12. Wallevik, O. H., Wallevik, J. E. Rheology as a Tool in Concrete Science: The Use of Rheographs and Workability Boxes Cement and Concrete Research 41 (12) 2011: pp. $1279-1288$.

http://dx.doi.org/10.1016/j.cemconres.2011.01.009
13. De Larrard, F., Sedran, T. Mixture-proportioning of Highperformance Concrete Cement and Concrete Research 32 (11) 2002: pp. 1699-1704. http://dx.doi.org/10.1016/S0008-8846(02)00861-X

14. Skripkiūnas, G. Properties and structure of construction conglomerates. Vitae Litera, Kaunas, 2007: pp. 225.

15. Roussel, N. Correlation between Yield Stress and Slump: Comparison between Numerical Simulations and Concrete Rheometers Results Materials and Structures 2006 (39) 2005: pp. 501-509.

16. Jau, W. C., Yang, C. T. Development of a Modified Concrete Rheometer to Measure the Rheological Behavior of Conventional and Self-consolidating Concretes Cement and Concrete Composites 32 (6) 2010: pp. 450-460.

17. Mehta, P., Monteiro, P. Concrete - Structure, Properties and Materials. 3rd . New York: McGraw-Hill; 2006.

18. Chidiac, S. E. Controlling the Quality of Fresh Concrete A New Approach Magazine of Concrete Research 52 (5) 2000: pp. $353-363$. http://dx.doi.org/10.1680/macr.2000.52.5.353

19. Wallevik, O. Rheology - a Scientific Approach to Develop Self-compacting Concrete International RILEM Symposium on Self-Compacting Concrete 2003: pp. 23-31.

20. Domone, P. L. Fresh Concrete. In: Advanced Concrete Technology: Concrete Properties. J. Newman and B.S. Choo (Eds.), Elsevier, 2003. http://dx.doi.org/10.1016/b978-075065686-3/50248-2

21. Bartos, P. J. M., Sonebi, M., Tamimi, A. K. Workability and Rheology of Fresh Concrete: Compendium of Tests Report of RILEM Technical Committee TC 145- WSM, Workability of Special Concrete Mixes RILEM Publications S.A.R.L, 2002 (Cachan Cedex). 